\title{
THE EDITOR LOOKS BACK OVER FIFTY YEARS OF THE JOURNAL
}

WHE FIFTY years separating the founding of the Journal by the Associated Friends of the Rutgers Library in 1937 and this celeL bration of the Journals half-centennial have witnessed a world war and a social revolution at home, both of which occurrences left the universities of this country, and their libraries, permanently altered. Rutgers shared the fate of its sister institutions after I 945 in accommodating-or rather, trying to accommodate - the thousands of war veterans who flocked to enroll under the provisions of the G.I. Bill. American higher education changed in the course of a very few years from an elite pursuit, available to only a small percentage of the nation's youth, to a mass phenomenon. Twenty years later, long-overdue recognition of the country's obligation to extend the benefits of full social and economic participation to its minorities, and to its women, led to the beginning of sweeping demographic changes, still in motion, in the faculties and student bodies of American universities.

The research agendas and curricula of our universities were as radically affected by World War II and the social changes of the I 960 s and I 970 O as were their student bodies and faculties. The science that had won the war for America was university-based science, and government-funded defense research, reinvigorated by Sputnik after I958, has continued since the war to play a significant role on American campuses. Science and technology were not the only areas affected by the infusion of government funding: The National Defense Education Act of I 958 also stimulated the humanities and social sciences through its support of strategic language and area studies. The social unrest of the I960s and I970s, centering on the civil rights movement and the war in Vietnam, led to a rearticulation of the university's role in the creation of a just society. The nation's most prestigious institutions began to develop new areas of study in their curricula such as black and womens' studies, both to encourage wider participation in their scholarly activities and to afford new insights into established fields of inquiry. And social concern about the uncontrolled 
exploitation of natural resources led the sciences to establish environmental studies in a variety of fields.

Rutgers was immune to none of these trends in American education during the last fifty years. In fact, the transformation of the university from a small constellation of institutions on the Raritan to an enormous state-wide complex probably accelerated the pace of social and curricular change at Rutgers. In I 945 Rutgers not only became the State University of New Jersey, bonded in a new configuration with the New Jersey College for Women and the State Experiment Station, but it also acquired the campus of the University of Newark. In 1950 it absorbed a law school and undergraduate program in Camden. During subsequent decades Rutgers greatly expanded the science campus begun across the Raritan in the I930s, and in I 969 opened, adjacent to the Busch science campus, an entirely new college focusing on urban studies. By I 987 the Rutgers University faculty numbered 2,400 , up from I00 in I 940 , and the university enrolled over 48,000 students

The effect of the proliferation of faculty, students and programs on library operations was enormous. A new library building on College Avenue replaced the old Voorhees library in 1956, and a whole congery of undergraduate and specialized libraries grew up to serve new programs and enrich research in older disciplines. In I 987 the nineteen libraries administered by the Rutgers University Librarian, Dr. Joanne Euster, contain 2,400,000 volumes and include specialized collections in science and medicine, art, music, law and jazz studies, to name only a few.

When the Journal of the Rutgers University Library was founded, its purpose was to publish articles on topics which were based on material in the Voorhees library, which then contained 300,000 volumes. Articles published in the first five years of the Journals history reflect that library's strength in the records of New Jersey's heroes, politics and great families. Philip Freneau, Revolutionary colonel John Neilson, Rutgers' eleven George Washington letters, and the first Congressional election in New Jersey, all are featured in those early years. The Editorial Board still retains as its primary mission the publicization of the research potential of Rutgers' collections, but the increased breadth of holdings in the main Department of Special Collections and Archives at Alexander Library, and the multiplicity of specialized libraries now in the university, permit of greater variety of Journal content than previously. In recent years, for example, we have been able to publish primary research based on New Jersey women's diaries and the papers of feminist Mary Cady Stanton; 
biographies of Rutgers' first Jewish and black graduates and of the first Democratic U.S. Congresswoman, Mary Norton, of Jersey City; and the histories of the university's collections of illustrated childrens' books, jazz recordings and publications, Soviet legal publications, and of its library of science and medicine.

The message from the President makes it clear that the next fifty years of Rutgers library development will be as dynamic as the past fifty. It is, of course, impossible to know what areas of science and scholarship will dominate American research over the next half century, but it is the hope of the Editor that the Journal will continue to communicate to the world outside Rutgers the resources its libraries offer for scholarly inquiry of all kinds.

Pamela Spence Richards Editor 